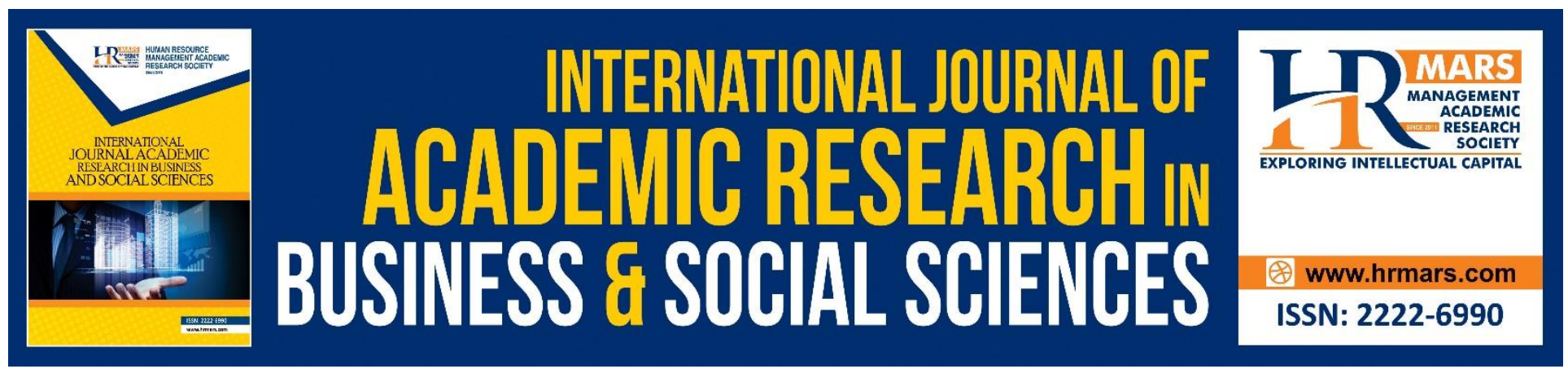

\title{
A Review on the Studies Conducted In Turkey on Creative Accounting and Professional Ethics
}

\author{
Nesegul Parlak, A. Taylan Altintas
}

To Link this Article: http://dx.doi.org/10.6007/IJARBSS/v9-i6/5992

DOI: 10.6007/IJARBSS/v9-i6/5992

Received: 17 April 2019, Revised: 13 May 2019, Accepted: 01 June 2019

Published Online: 27 June 2019

In-Text Citation: (Parlak \& Altintas, 2019)

To Cite this Article: Parlak, N., \& Altintas, A. T. (2019). A Review on the Studies Conducted In Turkey on Creative Accounting and Professional Ethics. International Journal of Academic Research in Business and Social Sciences, 9(6), 759-773.

Copyright: (C) 2019 The Author(s)

Published by Human Resource Management Academic Research Society (www.hrmars.com)

This article is published under the Creative Commons Attribution (CC BY 4.0) license. Anyone may reproduce, distribute, translate and create derivative works of this article (for both commercial and non-commercial purposes), subject to full attribution to the original publication and authors. The full terms of this license may be seen

at: http://creativecommons.org/licences/by/4.0/legalcode

Vol. 9, No. 6, 2019, Pg. 759 - 773

http://hrmars.com/index.php/pages/detail/IJARBSS

JOURNAL HOMEPAGE

Full Terms \& Conditions of access and use can be found at http://hrmars.com/index.php/pages/detail/publication-ethics 


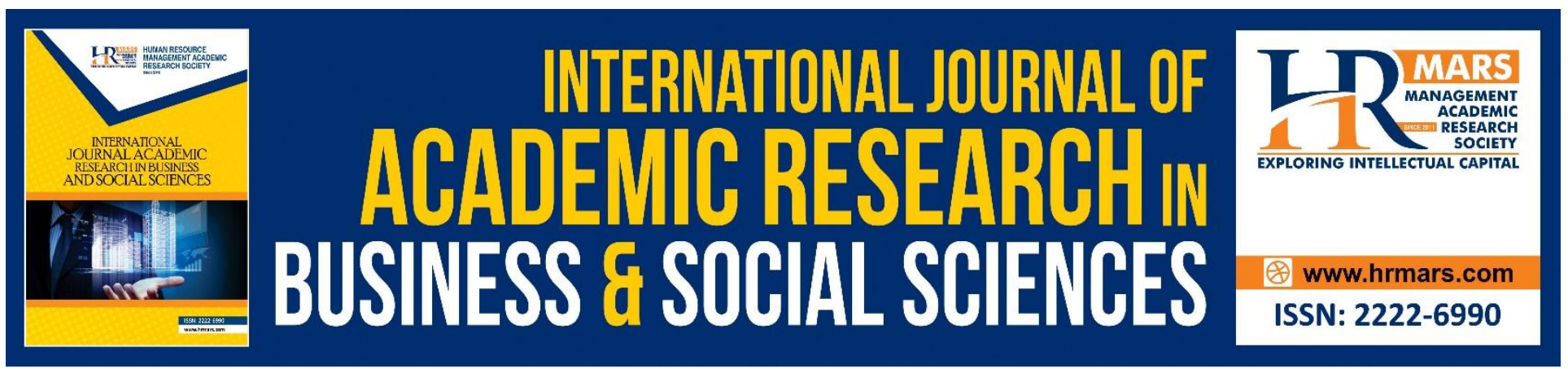

\title{
A Review on the Studies Conducted In Turkey on Creative Accounting and Professional Ethics
}

\author{
Nesegul Parlak ${ }^{1}$, A. Taylan Altintas ${ }^{2}$ \\ ${ }^{1}$ Ordu university, fatsa vocational school, lecturer, ${ }^{2}$ istanbul university, faculty of business \\ administration, associate professor, \\ Email: email:nparlak@odu.edu.tr, email:atayalana@istanbu.edu.tr
}

\begin{abstract}
Creative accounting, in accordance with the law and other legal regulations, is the set of practices performed for the purpose of presenting an enterprise much better than it is rather than the realistic and accurate presentation aimed by the accounting standards. The fact that creative accounting practices are not against the law does not necessarily mean that they are ethical, because the decisions made by the individuals who possess a professional ethics understanding are expected to produce positive results for the entire society. Therefore, creative accounting practices are faced with the problem of professional ethics as it prevents the parties interested in the reports to make the right decisions.
\end{abstract}

Keywords: Creative Accounting, Ethics, Ethical Dilemma.

\section{Introduction}

Accounting is a profession that produces the quality information needed by the interested parties in accordance with the generally accepted accounting principles (GAAP), the basic concepts of accounting, the accounting standards and the relevant legislation and needs to consider the benefits of the entire society. It is a requirement of the social responsibility concept for the professional accountants who produce accounting information to act in accordance with the professional ethical principles as well as their technical knowledge and skills. The information that the professionals will produce in accordance with professional ethical principles and rules will be both high quality and reliable.

A number of national and international regulations have been made on the ethical principles and rules that the professional accountants should follow when conducting their professional activities. The International Federation of Accountants (IFAC) and the American Institute of Certified Public Accountants (AICPA) are the two main international regulations. In our country, in the light of the international regulations we are a member of, a regulation on "Ethical Principles for Certified Public Accountants to observe in their Professional Activities" has been published and put into practice by the Union of Chambers of Certified Public Accountants of Turkey (TURMOB). Members of the 
profession will carry out their professional activities by abiding by these regulations and avoiding unethical behaviors, which will harm the trust and dignity of the profession.

Creative accounting practices performed within the framework of legal regulations prevent the healthy price formation and the formation of an effective market by creating unfair competition in the markets, manipulating financial information, and damaging the principle and rule of public disclosure and protection of investors. Creative accounting practices are applied by making choices among non-regulated and open to interpretation considerations and options that are at the discretion of practitioners as well as making use of the gaps and contradictions in legal regulations. As the main purpose in creative accounting practice is to mislead the parties that are interested in the reports by preparing and presenting them in a misleading manner, it is impossible to carry out these practices within the boundaries of professional ethics. In addition, it is of utmost importance to determine and measure these applications as they are carried out in accordance with the principles and rules of accounting.

The aim of this study is to attempt to explain the concepts of creative accounting and professional ethics and the professional ethical dilemma resulting from creative accounting practices. It also summarizes the studies made in Turkey and gives a broad view of the Turkish literature about the creative accounting.

\section{The Concept of Creative Accounting}

The concept of "creative" means "presenting something as one wishes" -by the book- and the exact opposite of "conservatism" and "consistency" according to GAAP (Dogan, 20011:5). Creative accounting is what accounting activities are named when reports are prepared that present a condition other than an enterprise is in by making use of the flexibilities in accounting principles and rules and the legal gaps (Lungu, Potecea and Rotaru, 2009: 1265). In other words, creative accounting can be defined as the entire set of activities that aim to present an enterprise's financial position differently than it is by doctoring accounting numbers and changing the style of financial reports and presentation of financial data through taking advantage of the flexibilities and deficiencies of accounting principles and rules, valuation criteria and regulations on applications (Siegel and Shim, 2005: 118). This concept, which is translated into Turkish as "yaratıc muhasebe" from its English original "creative accounting", stemmed from the necessity of creating a balance between interest groups and using this balance for the benefit of the enterprise without sacrificing the accounting principles and rules, and these practices are carried out with the sole purpose of increasing profits. Creative accounting is a broad concept that covers all practices that can be used to adjust reported financial results and change perceived business performance (Mulford and Comiskey, 2002: 49). The term of "Creative" in creative accounting refers to a positive situation only for the benefit of the enterprise and enterprise managers among the users of the accounting information (Genc and Kose, 2018:3). Creative accounting is a concept used to describe the negative conditions expressing the entirety of the methods and approaches used to conceal or change the undesirable current financial situation and activity results of the enterprise (Can, 2010: 30).

The process of creative accounting practices can be summarized as follows (Citak, 2009: 56).

- Practice does not begin with the idea of fraud.

- Practice starts with oppression. 
- At first, practice starts at a very small size.

- Practice starts in the vague, obscure, uncertain areas of financial reporting.

- Fraud and abuse grow over time.

- There is no longer a way out.

Creative accounting practices are applications that distort the GAAP by means of processing within or outside the GAAP (Mulford and Comiskey, 2004: 49) to influence the perceived performance of the enterprise and the reported financial results of the enterprise. Another definition of creative accounting can be given as the managers, by taking advantage of the generally accepted accounting principles and standards and missing regulations in the law, preparing and presenting the financial reports in a way that is contrary to the facts with the purpose of obtaining benefit sometimes directly and sometimes indirectly by presenting the enterprise as more successful than it is (CItak, 2009: 163). The fact that these practices use the deficiencies and flexibilities of accounting principles and standards on purpose and push the ongoing accounting system harms the users of accounting information.

The purpose of creative accounting practices is to show that the financial reports of the enterprise are better than they actually are by benefiting from the deficiencies and flexibilities of generally accepted accounting principles and standards. The purpose of creative accounting practitioners is to influence the quality of profit and also to affect the ratios used in the financial analysis by showing the enterprise's asset/resource structure and cash flow differently than they actually are. The reason for enterprises to gravitate towards creative accounting practices is mostly the inadequacies in accounting principles and rules.

Creative accounting practices also have the aim of presenting low costs and high profits, presenting the ratios used in financial analysis differently, concealing the financial risk that the enterprise may be facing and presenting the managerial performance as high. The operations of the creative accounting practices are legal since they are in accordance with the accounting principles and rules, however, they are unethical as they cause the interested parties to make wrong decisions by misleading them.

The subject of creative accounting practices is to cause the parties concerned to take wrong decisions for their own interests but in favor of the enterprise through the preparation and presentation of the financial reports by the company executives in a goal-oriented and unrealistic manner. Creative accounting practices are an unethical method used to present the financial reports secretly and covertly better than the reality for the benefit of the enterprise by going beyond professional ethics and traditions. Although for an enterprise to present its financial reports better is in compliance with accounting principles and rules, it is a practice used with the purpose of benefiting the enterprise by misinterpreting the existing regulations (Hsieh \& Tsai, 2006: 64).

Although creative accounting practices are carried out within the framework of existing laws and standards, they are clearly contrary to the essence and spirit of both (Kucuksozen, 2005: 80). They are used to conceal the essence of the transaction by giving priority to the form by leaving the concept of the priority of the essence out, which is one of the basic concepts of accounting. The practice is a process of preparing the financial reports by changing the accounting information, which is done by individuals who prepare the financial reports to choose rules that benefit them and ignore 
some principles and rules. The preferred option in this process is based on actual alternatives but also relative and is related to valuation (Stolowy and Breton, 2000: 48).

We can list the possible benefits of creative accounting practices to enterprises as below (Mulford and Comiskey, 2002: 4):

- The value of the company's shares in the stock market increases.

- The company's stock price decreases in mobility.

- The value of the company increases.

- It opens the way for a lower cost resource to the company.

- It increases the value of the company's stock options.

- It provides the company with borrowing opportunities with better conditions, lower costs and higher amounts.

- It provides high profit, high premium, and bonus.

- It creates fewer taxes and more profit distribution to the company.

- The legal pressure on the company decreases and high tax avoidance increases.

The advantages mentioned above are attractive and the deficiencies and flexibility in accounting regulations, principles and rules are encouraging and they create an environment suitable for creative accounting applications and directs the managers to choose the ones that benefit themselves.

The creative accounting practices often provide flexibility in the space inherent in accounting. Some of the issues related to standards, laws, principles, rules and regulations that limit the accounting practices are not explained in detail, and the right to choose gives managers a basis for abusing existing regulations and creative accounting practices (Aygun, 2013: 52). In particular, the fact that standards cannot simultaneously capture developments in real economic life leaves a field of application for creative accounting practices at all times. Likewise, leaving the initiative to the information producers in terms of the standards is also a reason for creative accounting practices (Genc \& Kose, 2018: 79). Another field of practice is for some accounting parties to obtain certain information before the other parties and to use this information for their own benefit (Genc and Kose, 2018: 99). These practices are considered to be less dangerous or worse than misleading financial reporting practices, even if they are not intentional (Mulford and Comiskey, 2002: 64).

Since creative accounting practices are made in accordance with GAAP, they are not wrong and accepted as legal. However, they can be expressed as applications that are not appropriate to the perception of professional ethics and even a kind of financial reporting fraud (Kassem, 2012: 31). These practices can damage trust in financial reports and cause damage to accounting information users (Riahi-Belkaoui, 2004).

In addition to deficiencies and flexibility in accounting principles and rules, their use out of purpose also paves the way for creative accounting practices. For example, the concept of accrual arising from GAAP enables the revenue period to be recovered and the operating profit can be shown to be higher or lower than it is in the future. In the same way, it is the subject of creative accounting, which will bring to mind the manipulation of the operating profit in the deliberations that will be made by the company management in the methods and timing of the distribution in a conscious manner.

In order to give more information to the parties interested in the financial reports of the enterprise, business managers may prefer the accounting options they wish only if they reflect the actual 
INTERNATIONAL JOURNAL OF ACADEMIC RESEARCH IN BUSINESS AND SOCIAL SCIENCES

Vol. 9, No. 6, June, 2019, E-ISSN: 2222-6990 @ 2019 HRMARS

financial position of the enterprise and are prepared in the light of objective data and if there are reliable indicators (Altuk Ozden and Ataman, 2014: 15).

\section{Accounting Professional Ethics}

Ethics is derived from the Greek word 'ethicos'. Ethics can be defined as "a set of moral principles, values and systems that studies what is beneficial along with concepts such as good, bad, right and wrong and determines what is good and what is bad in the behavior of both the individual and the group" (Hatcher, 2004: 358). Ethics refers to how to behave in order not to harm others and tells us what should be done in order to follow of the way of good (Ekici, 2013: 22). Occupational ethics is a set of professional principles that are created and preserved by a certain profession and aim to compel its members to behave according to a set of understanding, regulate the professional competition and protect the ideals of the profession (Sokmen, 2016: 36). In short, professional ethics can be expressed as a whole of the principles and rules that individuals belonging to a profession must follow when conducting the occupation (Ciftci and Ciftci, 2017: 108).

Professional ethics is the effort of an individual in order to construct their own moral culture, occupational qualities and social responsibility rules, regardless of the profession (Aymankuy and Sarıoglan, 2005: 30). It means that the members of the profession should act independently, ensure self-control and professional honesty. As in every profession, ethics has an important place in ethical professional activities of accounting profession (İsguden and Cabuk, 2006: 60-61). In order to maintain the credibility of the accounting profession in the society and to increase the reputation of the profession, in addition to professional technical knowledge and skills, professionals must act in accordance with professional ethics rules (Kutluk and Ersoy, 2011: 425). Protecting the social confidence in the accounting profession and to increasing the credibility of the profession will be possible by adapting to the code of ethics (Sakarya and Kara, 2010: 58).

According to IFAC, which is the most important internationally effective board of accounting profession, the basic principles that the professional accountant must follow are listed below in five terms (IFAC, 2015: 10):

- Honesty

- Objectivity

- Professional Qualification and Attentive Work

- Privacy (Confidentiality)

- Job Appropriate Behavior

Although within the framework of the ethical rules determined by IFAC the professional's use of creative accounting practices is not addressed directly, the issue is discussed indirectly in the explanations of the basic principles and principles of professional conduct. Since these rules are binding only within IFAC, the desired results at international level cannot be achieved in practice. Therefore, integrating the ethical principles and rules as a whole within the legal and other regulations of the countries will ensure that all ethical rules are attained to a legal basis and the creative accounting practices will be reduced to unimportant levels.

'The Regulation on Ethical Principles for Certified Accountants' Professional Practices', which was enacted within the scope of law no. 3568 on 19.01.2007, accepted the ethical principles 
INTERNATIONAL JOURNAL OF ACADEMIC RESEARCH IN BUSINESS AND SOCIAL SCIENCES

Vol. 9, No. 6, June, 2019, E-ISSN: 2222-6990 @ 2019 HRMARS

embraced by IFAC on 2006 and put them into practice. Furthermore, ethical principles according to the notification issued by $\mathrm{CMB}$ can be listed as follows:

- Professional Skepticism

- Independence

- Conditions Eliminating Independence

- Professional Care and Diligence

- Prohibition of Activity Against Trade and Occupation

- Advertisement Ban

- Secrecy Obligation

- Mutual Relations and Unfair Competition

In the decision processes related to the problems faced by professional members during their professional activities, taking into consideration the interests of the whole society and choosing the solution path in the light of professional ethical principles and rules will increase the confidence in the profession. As a result of the unethical behavior of professional members by applying creative accounting, some of the parties interested in accounting information will gain unfair gains and another part will be subject to loss of rights. As a result of unethical conduct of professional activities of the members of the profession, the fact that some users of information can be directly measured in monetary terms, and the other part is exposed to losses will adversely affect professional reputation and trust. Execution of professional activities by professionals in accordance with ethical principles and rules will increase the respectability of the profession among society and unethical behaviors will harm this prestige (Turk, 2004: 46).

In the periods of inflation and economic crisis, the tendency to hide the bad indicators in the financial statements, not attaching sufficient importance to the accounting profession and ethical values, and the inadequacy of the accounting professional institutions have had a negative impact on the quality of accounting in our country (Gencoglu and Ertan, 2012: 19).

\section{The Dilemma between Creative Accounting and Professional Ethics}

The problem of creative accounting is not only legal or structural, but also cultural and ethical. Not only how laws are structured and implemented, but also how laws are perceived are crucial (McBarnet, 2005: 38). For this reason, not only the law should be addressed on creative accounting, but also the attitudes of the law enforcers and individuals subject to the law should be examined (McBarnet, 2005: 38).

Creative accounting practices prevent the information on financial statements to be reliable, understandable, appropriate and comparable and prevent enterprises from seeing their actual financial situation. Therefore, these practices are contrary to professional ethical principles and rules. The concept of social responsibility, which is one of the basic concepts of accounting, states the necessity of considering the whole society's benefit rather than certain individuals and groups while carrying out accounting activities, preparing and presenting the financial statements. Therefore, it may be considered as unethical behavior for a professional accountant who is supposed be truthful, impartial and honest, to lie to the society by applying creative accounting. 
INTERNATIONAL JOURNAL OF ACADEMIC RESEARCH IN BUSINESS AND SOCIAL SCIENCES Vol. 9, No. 6, June, 2019, E-ISSN: 2222-6990 @ 2019 HRMARS

Creative accounting practices are an ethical problem that requires special attention; it is a deceptive, misleading picture of the financial position of the enterprise by reducing or even eliminating transparency and accuracy in the preparation and presentation of accounts (Gavai, 2010: 152-153). Creative accounting practices are challenging the principles of accounting profession. For this reason, professionals can resist the negative pressure around them by acquiring the necessary information and skills through receiving training on accounting ethical values and make ethical decisions (Usurelu et al., 2010: 355).

Creative accounting practices can be considered as a form of lying, as it is intentionally carried out to mislead users of the financial statements. It is therefore considered to be unethical and violates the social purpose of accounting (Archer, 1996: 65).

Professionals have the duty of presenting the financial position of the enterprise as accurately and realistically as possible and falsifying this information with creative accounting practices is an unfair behavior towards the potential investors, shareholders and board members who will make decisions about the enterprise and have a right to know the financial position of the enterprise (Duska et al. 2011: 136-137). In addition, the concept of full disclosure, which is another one of the basic concepts of accounting, requires the financial statements to be sufficient, clear and understandable in a way that will aid the individuals and organizations who will make use of the statements to make right decisions and they need to include appropriate full explanations for the parties in the market to approve that they have been informed (Duska et al., 2011: 138).

Ethical dilemma is the situation that occurs when one needs to choose the best option among two positive conditions or among two negative conditions (Sen, 20110: 16). The ethical dilemma is a problem that occurs when two different interest groups are in conflict and each of them comes up with an arguable case and is not easy to settle. The professional ethics dilemma arises when a professional's duties and responsibilities for a number of parties do not correspond with his/her duties and responsibilities for other parties or his/her own interests (Mintz, 1995: 250). Professionals often face ethical dilemmas during their professional activities. It may not always be possible for the decision-maker to make an ethical choice. The ethical decision often depends on the ethical perception of the decision maker. While professionals conduct their activities, professional ethical principles and rules help them determine what is right and what is wrong. Professionals must fulfill the responsibilities of the profession by making correct, honest, and consistent decisions. In order to ensure the efficiency and credibility of the profession, it is extremely important to have a commitment to professional ethical principles and rules and to be aware of an ethical social responsibility. Professional ethics standards prevent the professionals fall into an ethical dilemma and glorifies them in the eyes of the public since professional ethics standards create the sense of having a measurement tool on practice for the professionals.

Nowadays, intensive ethical pressures faced by professionals lead to ethical conflicts (Akdogan, 2003: 18). The ethical dilemma arises when the two conflicting sides have the correct arguments and the ethical decision is to choose the right one among the opposite sides through the individual's ethical values, while the unethical behavior (ethical deviation) is the option that does not conform to the ethical values. (Dastan et al., 2015: 77). Professional ethics is negatively affected by ethical dilemmas and ethical deviations. The ethical dilemma can be expressed as a process of instability in the event that there are truths that can be discussed on both sides of an event (Kutlu et al., 2012: 733). While 
solving a case, it can be expressed as a situation arising from the instability of decision makers in using their professional judgment. According to another definition, the ethical dilemma is the situation when the decision maker needs to decide for the benefit of other individuals and groups because he/she believes that is the right choice, even though this is not in his/her own best interest (Jones and George, 2008: 127). Ethical deviation occurs when the decision maker makes an unethical decision. Ethical deviation arises when the decision maker chooses selfish behavior or does not have ethical values.

Although all people have recognized some of the common ethical rules, different people interpret these rules in different ways in the light of their age and life experiences (Resnik, 2013: 1). In this case, it is important how decision-makers internalize ethical rules. The fact that a person claims that they are acting according to the law and in an ethical way even though they look for and exploit the gaps in the law, legislation and legislative arrangements and gain unfair advantage does not mean that person acts in an ethical manner, on the contrary, it is regarded as unethical behavior (KIlıc, 2017: 33). The identification and completion of these legal gaps is possible, but only after an unethical event.

Many aspects of the society (enterprises, investors, employees, lenders, government, workers'/employers' organizations etc.) are affected by the professional activities of professional accountants. According to the concept of social responsibility, the responsibility of a professional accountant is not only meeting the needs of the client or the employer, but also act with the responsibility of the whole society. In this process, it is essential to provide reliable information to the society by paying attention to laws, professional laws, generally accepted accounting principles, values and judgments. Professionals need to know the professional ethical principles and rules, and perform their profession based on these rules (Aymankuy and Sakarya, 2003: 189).

While conducting professional activities, the previously determined ethical principles and rules are guidelines for the decisions to be taken. What is crucial is for the professionals to determine and prefer the behavior that best suits ethical principles and rules in the decision-making phase.

Professional accountants face professional ethical dilemmas as a result of their work while conducting their professional activities. These ethical dilemmas can be summarized as follows (Hanson, 1993: 9):

- Disclosed financial statements are of great importance. Therefore, experiences such as individual or organizational pressures, taxes to be paid from operating profits, increasing the amount of profit shares of business owners are frequently encountered by accountants in their professions. Ethical behavior encourages accountants to ignore these pressures.

- Professional accountants are required to obtain accurate and reliable information. Therefore, they should use reliable, real information when conducting their activities.

- Ethical cracks occur when focusing on short-term profitability in enterprises. Unethical behaviors are at the forefront of increasing short-term profits. Both accountants and business managers should recognize that a long-term understanding is important in businesses and they should avoid ethical dilemmas.

In order to eliminate these ethical dilemmas, relevant regulations have been made in accounting profession and these regulations have been made in relation to professional vocational education as 
well as the accounting standards, auditing standards and occupational laws as well as professional ethics.

Professionals can take unethical decisions as a result of the ethical dilemmas they experience during their professional activities. In order to avoid these unethical behaviors, the determination of professional ethical principles and rules to guide them in the decision-making process may facilitate the decision-making process. A test has been developed by the Bentley College of Business Ethics in Boston in order to determine whether the behavior performed is in accordance with ethical principles and rules (Aydın, 2006: 32). The decision-maker must respond to the following six questions before deciding on a particular subject (Lambertoon and Minor, 1995: 333):

1. Is this true?

2. Is this fair?

3. If anyone is to suffer, who is this person?

4. Would you feel comfortable if the decision you made has made the news on the first page?

5. Would you tell that to your family, child, or relatives?

6. How does the event smell?

There are many factors that directly or indirectly affect the ethical decision-making processes of individuals. These are culture, personal characteristics, gender, age, religion, occupation and organizational activities (Ay, 2005: 48), variables depending on the individual's personality, situationdependent variables and whether there are opportunities in decision-making or not (Unsal, 2008).

For accounting profession ethical dilemmas and ethical decision-making are vital. National and international professional organizations have conducted many studies on this subject. In our country, the standards that must be followed by all professionals for professional ethics have been determined by TURMOB. These standards are "Job title and qualification, vocational training and knowledge, honesty, credibility and impartiality, secrecy, responsibility, social responsibility, independence and unfair competition" (Dastan, 2009: 287).

The solution of ethical dilemmas may be possible by the following steps (Kutlu, 2008: 151):

- Determining ethical dilemmas,

- Determining the key concepts related to the subject (responsibility to society, responsibility to employer, requirements of professionalism etc.),

- Collecting information about ethical dilemmas,

- Determination of decision options,

- Finding the best solution by doing ethical reasoning with available data, determining the satisfactory solution if there is no ideal solution.

The professional accountant is required to observe the interests of the whole society while conducting his/her professional activities. While producing and measuring accounting information, he/she uses the accounting concepts, principles and rules that are loaded with meaning by fiscally evaluating them. The production and measurement of accounting information cannot be made without these concepts, principles and rules. Accounting professional ethics is the integration of accounting concepts, principles and rules and ethical systems so that accurate and reliable information generation and measurements can be made. The basic principle in ethical dilemma process is to make the most appropriate decision with an objective approach within the framework of the principles and rules adopted. 
INTERNATIONAL JOURNAL OF ACADEMIC RESEARCH IN BUSINESS AND SOCIAL SCIENCES Vol. 9, No. 6, June, 2019, E-ISSN: 2222-6990 @ 2019 HRMARS

\section{Studies on the Dilemma between Creative Accounting and Professional Ethics In Turkey}

In the international literature, there are many studies on creative accounting and professional ethics. Although the studies conducted in our country have increased in recent years, they are relatively few. However, the concepts of creative accounting and professional ethics have been studied separately. In this section, we aim to give an overview of the studies that associate these two concepts in Turkey. In the study conducted by Akyel and Karaca (2005), the concept of ethics and its importance in terms of independent auditing were examined and creative accounting practices and $\mathrm{CMB}$ arrangements for the prevention of these practices were evaluated.

Bayırlı (2006), in his study that aimed to determine how academics and practitioners approach creative accounting and to determine the ethical boundaries of creative accounting, practitioner, regulatory and supervisory agencies, indicates that creative accounting is a very common problem and reveals that academicians think that creative accounting practices are a tool that can be used to give signals to capital markets as long as they remain within ethical limits.

Kirik (2007) evaluates error and deceit in terms of education and ethics in the study he conducted with 71 professional accountants in Afyonkarahisar. He determined that the professionals are exposed to intense demands and pressures by the customers in terms of cheating, that the inadequacy of the job density and the level of professional knowledge cause faulty transactions, and that customers, government policies and tax practices are effective on the basis of errors and deceit as much as accountants.

Citak (2009), in his study on determining whether creative accounting practices are fraudulent financial reporting or not, emphasizes, because the creative accounting practices are mostly carried out by top-level managers, the need to increase executive penalties for such false reporting and the need to give more responsibility to managers, and states that the independent and internal auditing should be enhanced.

Topsak (2009), as a result of his study conducted on relationship between the accounting errors and fraud and attitudes of professional accountants on unethical behavior, he concluded that although a vast majority of the professionals embrace the professional ethics principles they do not act in accordance with these principles and they do not act meticulously enough during their professional practices for various reasons.

Guney and Cinar (2012) identified that there is competition among professionals and that the professionals go beyond their ethical code and practice fraud in order to keep their customers in the survey they conducted with 102 professionals in the province of Erzurum on determining the perception of ethics of the professional accountants.

Cavusoglu (2019), in his study carried out with a survey done with 340 independent auditors that aimed to determine the effect of professional skepticism, ethical sensitivity and ethical state on the ability of independent auditors' for noticing the creative accounting practices, reaches to the conclusion that the independent auditors have a interpersonal understanding and an inquisitive mind in terms of professional skepticism, that they search for information, that in terms of their ethical state they are generally both idealists and relativists, and that they possess ethical sensitivity and an ability to notice creative accounting practices. 


\section{Conclusion}

Accounting information users obtain important information about an enterprise through financial reports and take some decisions about the enterprise by making use of this information. The practices that are carried out by the business managers for their own benefit, that present the financial situation of the enterprise differently for the purpose of misleading the users of accounting information and that affect the quality of the financial reports negatively are framed as creative accounting.

Although creative accounting practices are carried out by taking advantage of the gaps and flexibilities in accounting principles and rules and they are not contrary to the legal regulations, they are unethical practices since they do not comply with the professional ethical principles and rules. Therefore, creative accounting practices may be carried out by making use of issues that have not been addressed through legal regulations, that are open to interpretation, and that have several options regarding the same matter and contradictory legal regulations. The fact that financial reports prepared by professionals are true, accurate and reliable is very important for the whole society. All of these practices, which are done to deceive users and which undermine the credibility of the profession, harm the reputation and reliability of the profession, and the perception of professional ethics.

The whole society is affected by the negative consequences of the unethical behavior of the professionals. National and international efforts are being intensified in order to ensure that the professionals avoid using legal loopholes for unethical behavior and ensure compliance with ethical principles and laws. However, despite all efforts, it is a fact that the unethical and illegal activities of the professionals continue as a fundamental problem. The financial reports prepared in the light of professional ethics principles by minimizing the creative accounting practices will be realistic and of high quality.

With creative accounting practices, enterprises increase their profits and their net market value by increasing their revenues and reducing their expenses. It is believed that this study, which discusses the relationship between creative accounting and professional ethics and reviews the studies done in Turkey, will contribute to the literature of creative accounting and professional ethics.

This study demonstrates the views about creative accounting practices. It also provides with the information about viewpoint of the researchers and academicians in Turkey.

Further research can be made in this area by making a comparison of the views presented in the Turkish papers about the subject to those papers in similar countries.

\section{References}

Ozden, A. E., Ve Ataman, B. (2014). "Kar Yonetimi ve Yontemleri” Marmara Universitesi Oneri Dergisi, C.11, S.42, ISSN 1300-0845, ss.13-25.

Akdogan, H. (2003). "Muhasebe Meslek Etiginin Kamunun Aydınlatılmasındaki Onemine Meslek Mensuplarının Yaklasımı”. Eskisehir: TC Anadolu Universitesi Yayınları No: 1470.

Akyel, N., Ve Karaca, N. (2005). "Bagımsız Denetim Acısından Etik ve Yaratıcı Muhasebe Uygulamaları", Mali Cozum Dergisi, S. 72. ss. 242-254.

Archer, S. (1996). "The Ethics of Creative Accounting". Science and Engineering Ethics, 2(1): 55-70.

Ay, C. (2005). İsletmelerde etiksel karar almada kulturun rolu. Yonetim ve Ekonomi. 12 (2), ss. 31-52. 
INTERNATIONAL JOURNAL OF ACADEMIC RESEARCH IN BUSINESS AND SOCIAL SCIENCES

Vol. 9, No. 6, June, 2019, E-ISSN: 2222-6990 @ 2019 HRMARS

Aydın, i. (2006). Egitim ve ogretimde etik (2. Baskı). Ankara: Pegem A Yayıncılık.

Aygun, D. (2013). "Yaratıc Muhasebe Stratejileri", Eskisehir Osmangazi Universitesi iibf Dergisi, 8(2), ss.49-69

Aymankuy, Y., Ve Sakarya, S. (2003). "Finansal Piyasalar ve Meslek Etigi”, Hacettepe Universitesi, 1. Turkiye Uluslararası İs ve Meslek Ahlakı Kongresi.

Aymankuy, Y., Ve Sarıoglan, M. (2005). Muhasebe Meslek Mensuplarının Meslek Etigine Yaklasımları ve Balıkesir iı Merkezinde Bir Uygulama. Balıkesir Universitesi Sosyal Bilimler Dergisi, 8(14), 23-45.

Bayırlı, R. (2006), "Yaratıcı Muhasebe, Etik, Firma Degeri Ve Ornek Bir Uygulama" Doktora Tezi, Gazi Universitesi Sosyal Bilimler Enstitusu Muhasebe - Finansman Bilim Dalı. Ankara.

Can, A. V. (2010). "Kriz Muhasebesi ve Muhasebenin Krizi”, Mali Cozum Dergisi, S.97, ss.21-47.

Cavusoglu, K. (2019). "Bagımsız Denetimde Etik Ve Yaratıcı Muhasebe", Doktora Tezi, Akdeniz Universitesi Sosyal Bilimler Enstitusu, Antalya

Cıtak, N. (2009). Hileli Finansal Raporlamada Yaratıcı Muhasebe, Turkmen Kitabevi, İstanbul.

Ciftci, B. Ve Ciftci, Y. (2017). "Muhasebe Meslek Etigi Duzenlemeleri Cercevesinde Ihbarcılık", International Journal of Academic Value Studies (Javstudies) , Vol:3, Issue:11; pp:106-125 (ISSN:2149-8598).

Dogan, C. O. (2011). "Yaratıcı Muhasebe ve İstanbul Menkul Kıymetler Borsası'nda İslem Goren Sirketler Uzerinde Bir Uygulama", Yuksek Lisans Tezi, Gaziosmanpasa Universitesi, Sosyal Bilimler Enstitusu, Tokat.

Dastan, A. (2009). "Etik Egitiminin Muhasebe Egitimindeki Yeri ve Onemi: Turkiye Degerlendirmesi”, Marmara Universitesi iïB Dergisi, 26(1), 281-311.

Dastan, A., Bellikli, U. ve Bayraktar, Y.(2015). Muhasebe Egitiminde Etik Ikilem Ve Etik Karar Alma Konularına Yonelik KTU-iiBF Ogrencileri Uzerine Bir Arastırma, Ekonomik ve Sosyal Arastırmalar Dergisi, Cilt 11, Yıl 11, Sayı 1. ss. 75-92.

Duska, R., Duska, B. S. ve Ragatz, J. (2011). Accounting Ethics. Wiley-Blackwell, Chichester.

Ekici, K. M. (2013). Meslek Etigi, Savas Kitap ve Yayınevi, Ankara.

Hanson, E. (1993). "Financial Accounting An Introduction, Seventh Edition", The Dayden Press, Harcourt Brace College Publishers, s. 9.

Gavai, A. K. (2010). Business Ethics. Himalaya Publishing House, Mumbai.

Genc, M., Ve Kose, Y. (2018).“Yaratıcı Muhasebe Uygulamaları ve Turkiye'de Bagımsız Denetcilerin Sorumlulugu", Akademisyen Kitapevi, Ankara.

Gucenme Gencoglu, U. ve Ertan, Y. (2012). “Muhasebe Kalitesini Etkileyen Faktorler ve Turkiye'deki Durum", Muhasebe ve Finansman Dergisi,

Guney, S. Ve Cınar, O. (2012).Serbest Muhasebeci Mali Musavirlerin (SMMM) Etik Algıları: Erzurum Ornegi, Ataturk Universitesi İktisadi ve İdari Bilimler Dergisi, Sayı: 2 Cilt: 26, (91-106).

Hatcher, T. (2004). "Environmental Ethics As An Alternative For Evaluation Theory In For Profit Business Context", Evaluation And Program Planning, 27, 357-363.

Hsieh, L. F., Ve Y. T. Tsai, (2006). "Information Asymmetry, Creative Accounting and Moral Choice: An Apocalypse Of Procomp Informatic Ltd.", Journal Of American Academy Of Business, Cambridge, 6 (2). 
INTERNATIONAL JOURNAL OF ACADEMIC RESEARCH IN BUSINESS AND SOCIAL SCIENCES

Vol. 9, No. 6, June, 2019, E-ISSN: 2222-6990 @ 2019 HRMARS

İsguden, B. ve Cabuk, A. (2006). "Meslek Etigi Ve Meslek Etiginin Meslek Yasamı Uzerindeki Etkiler", Balıkesir Universitesi Sosyal Bilimler Enstitusu Dergisi, ss.59-86.

Jones, R. Gareth, George, Jennifer M. (2008). Contemporaray Management, fifth Edition, Mc Graw Hill Publication

Kassem, R. (2012). Earnings Management and Financial Reporting Fraud: Can External Auditors Spot the Diserence?", American Journal of Business and Management, 1 (1), 30-33

Kılıc, T. (2017). "Etik ve Sosyal Sorumluluk ( IIgili Kavramlar ve Aralarındaki Iliskiler)", Gazi Kitapevi.

Kirik, Z. (2007). Muhasebe Hata ve Hileleri ile Muhasebe Mesleginde Etik: Afyonkarahisar'da Muhasebeciler Uzerine Bir Arastırma, Yayınlanmamıs Yuksek Lisans Tezi, Anadolu Universitesi Sosyal Bilimler Enstitusu, Eskisehir.

Kutlu, H. A. Ve Dig. (2012). "Etik Ikilemden Cıkısta Kisisel Degerin Rolu: Muhasebe Meslek Mensupları Uzerinde Bir Uygulama", 1. Uluslararası Muhasebe ve Finans Sempozyumu, 31 Mayıs-2 Haziran, 733-746.

Kutlu, H. A. (2008). "Muhasebe Meslek Mensupları ve Calısanların Etik İkilemleri: Kars ve Erzurum illerinde Bir Arastırma", Ankara Universitesi Siyasal Bilgiler Fakultesi Dergisi, Sayı:2, Cilt:13, ss.143-170.

Kucuksozen, C. (2005). Finansal Bilgi Mamipulasyonu: Nedenleri, Yontemleri, Amacları, Teknikleri, Sonucları ve IMKB Sirketleri Uzerine Ampirik Bir Calısma, Sermaye Piyasası Kurulu Yayınları, No:183, Ankara.

Lambertoon, L. Minor, V., Leslie, H. (1995). Human relations: Stretegies for succes. Chicago: Irwin Mirror Pres.

Lungu, I., V., Potecea, Ve H., Rotaru, (2009). "Techniques Used In Creative Accounting", Annals Of DAAAM For 2009 \& Proceedings Of The 20th - International DAAAM Symposium, 20 (1) s: $1265-1266$.

McBarnet, D. (2005). “'Perfectly Legal': A Sociological Approach to Auditing”. T. Campbell ve K. Houghton (Ed.). Ethics and Auditing. ANU E Press, Canberra, 25-43.

Sakarya, S. Ve Kara, S. (2010). Turkiye'de Muhasebe Meslek Etigine Yonelik Duzenlemeler ve Meslek Mensupları Tarafından Algılanması Uzerine Bir Alan Arastırması. KMU Sosyal ve Ekonomik Arastırmalar Dergisi, 12(18), ss.57-72.

Siegel, J. G., Ve, J. K. Shim, (2005). Dictionary Of Accounting Terms, Fourth Edition, Barron's Educational Series.

Stolowy, H. Ve Breton, G, (2000). "A Framework fort he Classification of Accounts Manipulations", https://core.ac.uk/download/pdf/6276862.pdf, (Erisim Tarihi:20.05.2019).

Stolowy, H., Ve Breton, G. (2003). “Accounts Manipulation: A Literature Review and Proposed Conceptual Framework", Review of Accounting and Finance, Vol. 3 Iss: 1.

Sokmen, A. (2016). Meslek Etigi, Detay Yayıncılık, Ankara.

Sen, M. L., (2010). Kamu Gorevlileri Etik Rehberi, Basbakanlık Kamu Gorevlileri Etik Kurulu Yayını, Ankara.

Mintz, S. M. (1995). "Virtue Ethics and Accounting Education", Issues In Accounting Education, 10(2):247-267.

Mulford, C.W., Comiskey, E.E. (2002). The Financial Numbers Game: Detecting Creative Accounting Practice, John Wiley \& Sons, USA. 
Resnik, D. B. (2013). "What is etchics in Research \& Why is it important?", Ulusal Saglık Bilimleri Enstitusu.

Riahi-Belkaoui, A. (2004). Accounting leory, 5th Edition, London: "omson. Alıntı Al-khabash, A. A. \& Al-"uneibat, A. A. (2009). Earnings Management Practices from the Perspective of External and Internal Auditors: Evidence from Jordan. Managerial Auditing Journal, 24 (1), 58-80.

Usurelu, V. I., Marin (Nedelcu), M., Danaila (Andrei), A. E. ve Loghin, D. (2010). “Accounting Ethics Responsibility versus Creativity". Annals of the University of Petrosani, Economics, 10(3): 349356.

Unsal, A. (2008). "İsletmelerde muhasebe yoneticilerinin etiksel karar sureci". KMU iiBF Dergisi, 10(14).

Topsak, F. (2009). "Muhasebe Meslek Mensuplarının Hata, Hile Ve Meslek Etigi Konularındaki Tutumları Uzerine Bir Arastırma: Ankara Ve Balıkesir Ornegi", Ankara Universitesi, Sosyal Bilimler Enstitusu, İsletme Anabilim Dalı, Ankara.

Turk, Z. (2004). Muhasebe Meslek Ahlakı, Nobel Kitabevi, Adana. 